\title{
Antioxidant and antimicrobial activity of gamma irradiated chicory (Cichorium intybus L.) leaves and roots
}

\author{
Khalaf, H.H.A ${ }^{1}$; El Saadani, R.M.A. ${ }^{1}$; EL Desouky, A.I. ${ }^{1}$; Abdeldaiem, M.H² and El Mehy, M.E ${ }^{2}$ \\ 1- Food Tech. Dept., Fac. of Agric., Benha Univ., Egypt \\ 2- Nuclear Res. Cent., Atomic Energy Authority, Cairo, Egypt
}

\begin{abstract}
The objective of this study is to evaluate the efficacies of the ethanolic and methanolic $50 \%$ extracts of gamma irradiated chicory (Cichorium intybus L.) leaves and roots powder at dose levels of 0, 4, 8 and $12 \mathrm{kGy}$ as antioxidant and antimicrobial. The total phenolic contents (TPC) and total flavonoid contents (TFC) were determined in leaves and roots extracts followed by identification and quantification of the phenolic compounds using HPLC. The antioxidant activity was determined by DPPH and FRAP methods, as well as, the antimicrobial activity was verified by agar well diffusion assay against $B$. cereus, $S$. aureus, E. coli, P. aeruginosa, K. pneumonia, A. niger and $P$. expansum. The obtained results showed that, 4 and $12 \mathrm{KGy}$ doses significantly increase the TPC, TFC and enhanced the antioxidant activity of roots and leaves, respectively. Furthermore, twenty three phenolic components were identified in both leaves and roots extracts. The antimicrobial assay in vitro of all extracts exhibited considerable antibacterial activity against of all tested bacterial strains with slightly differences between plant part extract and had no effects against tested fungal strains. Therefore, the extracts of chicory under study would be a potential source of natural antioxidant and antibacterial and offers lots of opportunities for future application in food industry to produce healthy food and can be used in pharmaceutical industry.
\end{abstract}

Key words: Chicory leaves and roots/Antioxidant/ Antimicrobial/ Irradiation

\section{Introduction}

Phytochemicals in plants are broadly grouped into phenolic compounds, terpenoids, essential oils, alkaloids, lectins and polypeptides. The phenolic compounds also include simple phenols and phenolic acids, quinones, flavonoids and tannins. Phenolic compounds are secondary metabolites and one of the most widely occurring phytochemicals in plants. Phytochemicals, the plant-derived non-nutritive compounds, are one of the different types of the dietary factors which play an important role in various functions of the human body. A huge number of natural compounds present in food materials have been reported to possess antioxidant properties due to the presence of hydroxyl groups in their structure (Shui and Leong, 2004).

Cichorium intybus L. commonly known as chicory a member of the Asteraceae family and widely grown in Europe, Western Asia, Egypt, and North America. Historically, chicory was grown by the ancient Egyptians as a medicinal plant, vegetable crop and was occasionally used for animal forage. Greeks and Romans also grew chicory as a vegetable crop; its use was mentioned by several ancient writers (Mulabagal et al., 2009).

Chicory often found on our tables as a vegetable, and highly appreciated for its bitter taste. The young leaves can be added to salads and vegetable cuisine, while chicory extracts are used for production of invigorating drinks (Denev et al., 2014). The leaves are good sources of phenols, vitamins $\mathrm{A}$ and $\mathrm{C}$, as well as potassium, calcium, and phosphorus (Mulabagal $\boldsymbol{e t}$ al., 2009). Young and tender roots can also boiled and eaten. Chicory extracts are added to alcoholic and non-alcoholic beverages. In the 1970s, it was discovered that the roots of chicory contained up to $40 \%$ inulin, which has a negligible impact on blood sugar and thus is suitable for diabetics. Inulin is used to replace fat or sugar and reduce the calories of food (Judzentiene and Udiene, 2008).

Chicory has gained attention for its content of important phytochemicals which distributed throughout the plant; however, the primary contents are present in the roots and the leaves with nutraceuticals potential, such as phenolic acids, flavonoids, coumarin, cinnamic and quinic acid derivatives, and anthocyanins. In addition to the phytochemicals mentioned, all parts of this plant possess great importance due to the presence of compounds with putative health benefits, such as alkaloids, inulin, sesquiterpene lactones, vitamins, chlorophyll pigments, unsaturated sterols, saponins, and tannins (Sudhanshu et al., 2012 and Khan et al., 2014).

The antimicrobial and antioxidant activity of chicory leave, root and seeds extracts have been widely studied. The plant extracts were shown to inhibit the growth of several foodborne pathogens. Several studies (Sarvankumar et al., 2011; Shaikh et al., 2012; Eslami, 2015; Faiku et al., 2016) have been reported the efficacy of various extracts from the different parts of the plant against the growth of gram positive, gram negative bacteria and have antifungal properties. C. intybus has potential source of natural 
antioxidants and can be used for the treatment of diseases caused by the test organisms.

Synthetic antioxidants, such as butylated hydroxy anisole (BHA), butylated hydroxytoluene (BHT), and tert-butyl hydroquinone (TBHQ) can significantly delay lipid oxidation however they are limited to their use as additive agents in food systems because they might contain many factors hazardous to health. Thus antioxidants and antibiotics derived from natural resources are perceived by consumers as being better and safer than synthetics (Javed et al., 2011).

Irradiation can influence the levels of antioxidants/phytochemicals and the capacity of a specific plant to produce them at different levels. It has been reported that under certain favorable conditions, the concentration of plant phytochemicals might be enhanced. These conditions include exposure to radiation sources, wounding, storage at low temperatures, and/or exposure to extreme temperatures. In terms of exposure to radiation sources, this depends on the dose applied (usually low and medium doses have insignificant effects on antioxidants), the sensitivity of the antioxidant or the phytochemicals towards irradiation, and the effect of irradiation itself on other food constituents that might be responsible for the production and/or the accumulation of phytochemicals/antioxidants in the plant (Alothman et al., 2009).

There is no information available on the effect of ionizing radiation on the phytochemical contents, antioxidant and antimicrobial activities of chicory. Therefore, this study was intended to evaluate the effect of gamma irradiation on the antioxidant and antimicrobial efficacies of the ethanolic and methanolic $50 \%$ extracts of chicory (Cichorium intybus L.) leaves and roots powder at dose levels of $0,4,8$ and $12 \mathrm{kGy}$.

\section{Materials and Methods}

\subsection{Chicory (Cichorium intybus L.) samples:}

The freshly whole plant of chicory was collected directly from agricultural field in Moshtohor, Toukh city, Qalioubeya Governorate. The leaves and roots were separated manually with sharp knife, washed with tap water many times to remove soil particles and cut into small pieces then dried at $45 \mathrm{C}^{\circ}$ for $72 \mathrm{~h}$ in drying oven. Finally, the drying plant material was grinded using an electric blender (moulinex, France) to obtain fine powder of plant. The ground chicory samples were macerated in hexane to remove fatty materials, then dried at $70^{\circ} \mathrm{C}$ to remove hexane residue. The samples were packaged in polyethylene pouches $(100 \pm 2 \mathrm{~g})$ to procedure gamma irradiation treatment.

\subsection{Test organisms strains:}

Two gram positive strains Bacillus cereus (ATCC 33018) and Staphylococcus aureus (ATCC 20231), and three gram negative strains Escherichia coli
(ATCC 35218), Klebsilla pneumonia (ATCC 13883) and Pseudomonas aeruginosa (ATCC 9027) were obtained from the microbiological resources center (MIRCEN), Faculty of Agriculture, Ain Shams University, Cairo, Egypt. Aspergillus niger (ATCC 16404) and Penicillium expansum (ATCC 28877) strains were obtained from the Regional Center for Mycology and Biotechnology, Faculty of Science, ElAzhar University, Cairo, Egypt.

\subsection{Chemical composition of chicory:}

Moisture content, crude protein, ether extract and ash content were determined using method recommended in A.O.A.C. (2012) while, total carbohydrates was calculating by differences between one hundred and summation of the percentage of moisture, protein, fat and ash contents.

\subsection{Irradiation treatments:}

Chicory powder samples were exposed to gamma irradiation at dose levels of $0,4,8$ and 12 using a ${ }^{60} \mathrm{Co}$ Russian gamma chamber, (dose rate $1.3 \mathrm{kGy} / \mathrm{h}$ ), belonging to Cyclotron Project, Nuclear Research Center, Atomic Energy Authority, Cairo, Egypt.

\subsection{Preparation of the extracts of chicory:}

The extraction procedure for the hydroalcoholic extracts was carried out as reported by (Saggu et al., 2014). The non-irradiated and gamma irradiated chicory powder samples were extracted by direct soaking with ethanol $50 \%$, (for leaves) and methanol $50 \%$ (for roots). Briefly, $20 \mathrm{~g}$ of plant material was soaked with $200 \mathrm{ml}$ of solvent in dark bottles for $72 \mathrm{~h}$ at room temperature by shaking the mixture. After that, the resulting extract was filtered through filter paper (Whitman No.42). The residue from the filtration was extracted again twice using the same procedure. The filtrates were concentrated in vacuum using a rotary evaporator at $45^{\circ} \mathrm{C}$. The extracts were stored at $-18^{\circ} \mathrm{C}$ until analyses.

\subsection{Determination of total phenolics content (TPC): \\ Total phenolics content was determined by} the Folin- Ciocalteu method according to ArabshahiDelouee and Urooj (2007). Total phenolics content expressed as mg Gallic acid equivalent (GAE) /100g on dry weight (DW).

\subsection{Determination of total flavonoids content (TFC):}

Total flavonoids content were determined using the spectrophotometric method according to (Ordon et al., 2006) and expressed as mg quercetin equivalent (QE) /100g on dry weight (DW).

\subsection{Fractionation and identification of phenolic compounds in chicory leaves and roots extracts:}

Phenolic compounds of non-irradiated and irradiated leaves and roots powder at 12 and $4 \mathrm{kGy}$, respectively extracts were determined by HPLC according to the method of Goupy et al. (1999). The 
concentration of an individual compounds was calculated on the basis of peak area measurement then converted to mg phenolic / $100 \mathrm{~g}$.

\subsection{Antioxidant activity of chicory extracts:}

2.9.1. 2,2-diphenyl-1-picrylhydrazyl radicalscavenging activity (DPPH):

The electron donation ability of the obtained extracts was measured by bleaching of the purple colored solution of DPPH according to the method of Brand-Williams et al. (1995).

\subsubsection{Ferric reducing antioxidant power} (FRAP):

Reducing power of all extracts was measured according to the method of Oyaizu (1986).

\subsection{Antimicrobial activity of chicory extracts:}

Antibacterial activity of non-irradiated and gamma irradiated chicory leaves and roots powder extracts were assessed by agar well diffusion method as described by (Baydar et al., 2004 and Shin and Lim, 2004). The antibacterial activity was expressed as the diameter of inhibition zones produced by the extracts against tested bacteria in $\mathrm{mm}$.

\subsection{Statistical analysis:}

Data were analyzed using SPSS analytical software version 18.0 (SPSS Inc., Illinois, USA). Data were subjected to one-way analysis of variance (ANOVA) followed by Duncan test for comparison of means as a post-hoc test. Significant levels were based on the confidence level of $95 \%(\mathrm{p}<0.05)$.

\section{RESULTS AND DISCUSSION:}

\subsection{Chemical composition of chicory:}

The gross chemical composition of chicory plant (leaves and roots) is shown in Table (1). It was clear that, chicory leaves contain high levels of moisture, protein, crude ether extract and ash contents; and had low level of total carbohydrates compared to roots, which they were $(85.77,10.22,2.54,15.13$ and $72.11 \%)$ and $(76.32,3.83,0.95,4.45$ and $90.77 \%)$ for leaves and roots, respectively. These Results are fairly close to the results obtained by Monti et al., 2005 and Massoud et al., 2009. The difference in chemical composition is due to different environmental factors, climate, soil nature, fertilization, irrigation etc.

Table (1): Chemical composition of chicory (Means \pm SE).

\begin{tabular}{lcc}
\hline Components $(\boldsymbol{\%})$ & Leaves & Roots \\
\hline Moisture & $85.77 \pm 0.15$ & $76.32 \pm 0.2$ \\
\hline Crude protein* & $10.22 \pm 0.26$ & $3.83 \pm 0.35$ \\
\hline Ether extract* & $2.54 \pm 0.07$ & $0.95 \pm 0.04$ \\
\hline Ash* & $15.13 \pm 0.74$ & $4.45 \pm 0.32$ \\
\hline Total carbohydrate* & $72.11 \pm 0.11$ & $90.77 \pm 0.17$ \\
\hline *on dry weight basis & &
\end{tabular}

\subsection{Effect of gamma irradiation on total phenolic} content (TPC) of chicory leaves and roots extracts:

For irradiated leaves samples, the ethanolic extract of irradiated leaves at dose level of $12 \mathrm{KGy}$ has a clear significant $(p<0.05)$ increase in the total phenolic contents as compared to that of the control sample and other doses, which it was 865.91in control and increased to $918.47 \mathrm{mg}$ GAE $100 \mathrm{~g}$ (DW) after irradiation treatment. While, the TPC of irradiated leaves at dose levels of 4 and $8 \mathrm{KGy}$ was slightly decreased to 779.90 and 844.63 , respectively as shown in Table (2). These results are in agreement with Khattak (2013) who indicated that, the irradiation treatment for Emblica offcinalis up to the dose level of $12 \mathrm{KGy}$ increased the levels of phenolics and flavonoids and enhanced the DPPH scavenging activity and extraction yields of the methanol and aqueous extracts of the samples.

The increase of phenolics content could be attributed to the higher extractability of these compounds in irradiated samples as a result of alternations in cellular compounds and release of bound or insoluble phenolics especially at high doses of irradiation (Behgar et al., 2011).
In the case of roots, as shown in Table (2) the irradiation treatment had the same manner of acting for TPC of chicory leaves. As evidenced by the results, the greatest quantity of phenolic compounds was found in the methanolic extract of the irradiated sample by $4 \mathrm{KGy}$. It had a significant increasing in TPC which was 692.22 , compared to control sample $584.77 \mathrm{mg} \mathrm{GAE} / 100 \mathrm{~g}$ DW. While, that samples which treated by gamma irradiation at dose levels of 12 and 8 KGy had a significant decrease in TPC 557.85 and $613.07 \mathrm{mg}$ GAE/100g DW, respectively. Similar decrease in the polyphenols content was reported by Yalcin et al. (2011) and Ben Salem et al. (2013) in the irradiated Salvia officinalis leaves and Clary sage seeds at dose levels of 4 and $5.5 \mathrm{KGy}$, respectively.

\subsection{Effect of gamma irradiation on total flavonoids} content (TFC) of chicory leaves and roots extracts:

From the results in Table (2), it's clear that the flavonoid contents of the control samples were found to be 112.38 and $47.34 \mathrm{mg} \mathrm{QE} \mathrm{/100g} \mathrm{DW} \mathrm{for} \mathrm{leaves}$ and roots, respectively.

For gamma irradiation processed samples, the dose of $12 \mathrm{KGy}$ obviously affected the production of flavonoids and caused a significantly $(P<0.05)$ higher contents in the ethanolic extract of leaves sample 
124.15 as compared to that of other doses and the control samples. However, there were no significant differences $(P>0.05)$ between flavonoids content of irradiated samples at dose levels of 4 and $8 \mathrm{KGy}$, which were 108.42 and $106.48 \pm 0.40 \mathrm{mg} \mathrm{QE} / 100 \mathrm{~g}$ (DW), respectively. Destructive oxidation process in combination with ionizing energy could also cause breakages in the chemical bonds of the complex flavonoids, thereby releasing soluble flavonoids of low molecular weight. These low molecular weight flavonoids might have been highly soluble in the ethanol solvent (Darfour et al., 2014).

On the other hand, the methanolic extract of roots sample exposed to $4 \mathrm{KGy}$ dose showed a significant increase in TFC, it estimated to be 51.41 compared to control sample 47.34 mg QE /100g (DW) followed by $8 \mathrm{KGy}(47.80)$ and $12 \mathrm{KGy}(46.80) \mathrm{mg}$ QE $/ 100 \mathrm{~g}$ (DW) . However, the irradiation doses 8 and $12 \mathrm{KGy}$ did not cause significantly changes in the total flavonoids content of the samples. Flavonoids is one of the polyphenol groups, thus the decrease of flavonoids content could be associated with the decrease of polyphenol content. In agreement with these results, Moosavi et al. (2014) showed that, the flavonoids content of irradiated stored almond hull extracts at the doses of 2 and $6 \mathrm{kGy}$ was decreased by about $35 \%$ while, at $10 \mathrm{KGy}$ there was nonsignificant effect on TFC value compared to control sample.

Table 2.Total phenolic and flavonoid contents of the non-irradiated and irradiated chicory leaves and roots powder extracts.

\begin{tabular}{|c|c|c|c|c|}
\hline \multirow[b]{2}{*}{ Dose (KGy) } & \multicolumn{2}{|c|}{ TPC (mg GAE $\left.100 \mathrm{~g}^{-1} \mathrm{FW}\right)$} & \multicolumn{2}{|c|}{ TFC (mg QE $\left.100 \mathrm{~g}^{-1} \mathrm{FW}\right)$} \\
\hline & Leaves & Roots & Leaves & Roots \\
\hline 0 & $865.91^{\mathrm{Ba}} \pm 1.666$ & $584.77^{\mathrm{Cb}} \pm 2.424$ & $112.38^{\mathrm{Ba}} \pm 0.828$ & $47.34^{\mathrm{Bb}} \pm 0.728$ \\
\hline 4 & $779.90^{\mathrm{Da}} \pm 1.337$ & $692.22^{\mathrm{Ab}} \pm 2.233$ & $108.42^{\mathrm{Ca}} \pm 0.679$ & $51.41^{\mathrm{Ab}} \pm 0.583$ \\
\hline 8 & $844.63^{\mathrm{Ca}} \pm .527$ & $613.07^{\mathrm{Bb}} \pm 1.577$ & $106.48^{\mathrm{Ca}} \pm 0.405$ & $47.80^{\mathrm{Bb}} \pm 0.577$ \\
\hline 12 & $918.47^{\mathrm{Aa}} \pm .400$ & $557.85^{\mathrm{Db}} \pm 1.499$ & $124.15^{\mathrm{Aa}} \pm 0.615$ & $46.80^{\mathrm{Bb}} \pm 0.665$ \\
\hline
\end{tabular}

Values are expressed as mean \pm standard error, means with the same capital letter in the same columns are not significantly different $(p>0.05)$; Means with the same small letter in the same rows are not significantly different $(p>0.05)$.

\subsection{Identification and quantification of phenolic compounds in chicory leaves and roots extracts using HPLC:}

The results presented in Table (3) showed the separation of a large number of compounds, which twenty three phenolic compounds were identified. Several phenolic acids were found in the extracts of chicory leaves and roots: hydroxybenzoic acids (gallic acid, benzoic acid, ellagic acid, salicylic acid and evanillic acid), hydroxycinnamic acids (cinnamic, caffeic, chlorogenic, Ferulic and $p$-coumaric) and its derivatives. Besides these, many phenolic compounds were also found i.e. Pyrogallol, Catechein, Catechol, Epicatachin and Protocatechuic. The results are in agreement with previous findings (Carazzone $\boldsymbol{e t}$ al., 2013, Papetti et al., 2017 and Sahan et al., 2017) whose reported the presence of some of these phenolic compounds.

Among the identified phenolic acids, the chlorogenic acid contributes the higher amount to the total phenolic components level of the ethanolic chicory leaves extracts $(272.48 \mathrm{mg} / 100 \mathrm{~g})$ followed by e- vanilic acid, catechein, ellagic acid, benzoic acid and caffene. Chlorogenic acid is widely recognized to be active because of its free radical scavenging properties. It inhibits the peroxidation of linoleic acid and acts as a cancer chemo-preventive agent (Clifford, 2000). While, the major predominant phenolic compounds in the methanolic chicory roots extracts were found to be the catechein, benzoic acid, pyrogallol, e-vanilic acid, ferulic acid and chlorogenic acid which amounted to $91.59,75.04,47.26,45.26$, 43.42 and $30.51 \mathrm{mg} / 100 \mathrm{~g}$ of the phenolic compound contents, respectively.

The irradiation treatment had a prominent effect on the amount of total phenolics compound in both leaves and roots extracts. Twelve KGy dose leads to an increase in the phenolics content of leaves ethanolic extract. For example, the concentration of benzoic acid, chlorogenic acid, ellagic acid and gallic acid were increased from 77.50, 272.48, 91.19 and 1.52 to $85.52,447.49,147.89$ and $3.72 \mathrm{mg} / 100 \mathrm{~g}$, respectively. In contrast, the irradiation treatment led to decrease of some phenolics content; the amount of catechein and iso-ferulic acid was decreased from 96.40 and 49.10 to 88.30 and $47.97 \mathrm{mg} / 100 \mathrm{~g}$, respectively and caused to disappear of alpha-cumaric after irradiation treatment. Thus, the increase of phenolic acids (caused by irradiation at dose $12 \mathrm{kGy}$ ) will provide the plant with higher bioactivity. These results are agreement with Breitfellner et al. (2002) and Pereira et al. (2017).

Concerning roots, the same trend was observed in the methanolic extracts of roots. The irradiation at dose level of $4 \mathrm{KGy}$ was increased the concentration of benzoic acid, chlorogenic acid, caffene, e- vanilic acid and ellagic acid form 75.04, 30.52, 16.49, 45.69 and 7.17 to $317.58,203.92,44.42,173.01$ and 25.07 $\mathrm{mg} / 100 \mathrm{~g}$, respectively. 
Table 3. Identified phenolic compounds of non-irradiated and gamma irradiated chicory leaves and roots powder extracts by HPLC (mg/100g DW):

\begin{tabular}{|c|c|c|c|c|}
\hline \multirow{3}{*}{$\begin{array}{c}\text { Phenolic } \\
\text { Compounds }\end{array}$} & \multicolumn{4}{|c|}{ Phenolic compounds (mg/100g DW) } \\
\hline & \multicolumn{2}{|c|}{ Leaves } & \multicolumn{2}{|c|}{ Roots } \\
\hline & 0 kGy & $12 \mathrm{kGy}$ & 0 kGy & 4 kGy \\
\hline Pyrogallol & 21.41 & 109.77 & 47.27 & 23.10 \\
\hline Gallic acid & 1.52 & 3.72 & 1.09 & 1.20 \\
\hline 4- Amino-benzoic & 8.61 & 20.41 & 26.12 & 30.70 \\
\hline Protocatechuic & 7.98 & 14.81 & 6.47 & 8.92 \\
\hline Catechein & 96.41 & 88.30 & 91.59 & 56.72 \\
\hline Catechol & 5.13 & 10.72 & 5.33 & 2.82 \\
\hline Chlorogenic acid & 272.48 & 447.49 & 30.52 & 203.92 \\
\hline Epicatachin & 13.12 & 33.47 & 5.57 & 7.11 \\
\hline P-OH-benzoic & 11.93 & 38.39 & 12.42 & 16.67 \\
\hline Caffene & 68.76 & 158.36 & 16.49 & 44.42 \\
\hline Vanillic acid & 30.66 & 42.73 & 24.93 & 22.27 \\
\hline Caffeic acid & 1.27 & 3.35 & 3.50 & 0.90 \\
\hline$P-$ cumaric & 22.84 & 42.02 & 5.34 & 30.60 \\
\hline Ferulic acid & 5.85 & 51.76 & 43.43 & 15.05 \\
\hline Iso - ferulic acid & 49.10 & 47.97 & 8.13 & 45.27 \\
\hline e- vanilic acid & 131.02 & 270.79 & 45.69 & 173.02 \\
\hline Benzoic acid & 77.50 & 85.52 & 75.04 & 317.58 \\
\hline Ellagic acid & 91.19 & 147.89 & 7.17 & 25.07 \\
\hline Alpha - cumaric & 7.58 & -- & 0.90 & -- \\
\hline Coumarin & 11.10 & 15.00 & 8.08 & 15.14 \\
\hline 3, 4,5-methoxy-cinnamic & 6.37 & 18.36 & 5.17 & 7.88 \\
\hline Salycilic acid & 15.76 & 73.60 & 9.68 & 12.97 \\
\hline Cinnamic acid & 0.70 & 2.39 & 0.40 & 0.94 \\
\hline
\end{tabular}

\subsection{Antioxidant activity of chicory leaves and roots} extracts:

\subsubsection{2,2-diphenyl-1-picrylhydrazyl radical-} scavenging activity:

The radical scavenging activity of the extracts of non-irradiated and irradiated plant samples were analyzed using DPPH radical. The reduction capability of DPPH was determined by the decrease in its absorbance at $517 \mathrm{~nm}$ induced by antioxidants. The results obtained from the DPPH radical experiment were expressed as \% and tabulated in Table (4).

The DPPH radical scavenging activity after $60 \mathrm{~min}$ of the control samples of leaves and roots were 80.95 and $69.73 \%$, respectively. The results are close to which obtained by Kaur et al. (2016) they revealed that, the DPPH free radical scavenging activity reached to maximum values 78.62 and $71.88 \%$ in the methanolic extracts of chicory leaves and roots, respectively.

For irradiated leaves samples, the data showed that, all of the assessed ethanolic leaves extracts were able to reduce the stable purple-colored radical DPPH into yellow-colored DPPH-H. Irradiation resulted in a slight increase in the DPPH radical-scavenging ability of the extracts at dose levels of 4, 8 and $12 \mathrm{KGy}$ compared to control sample and the synthetic antioxidant BHT which exhibited the lowest scavenging activity with the lowest value $65.11 \%$ after $60 \mathrm{~min}$. It was observed that, as irradiation dose was increase the antioxidant activity also increased for DPPH radicals scavenging and reached to $82.89 \%$ in the extract of irradiated leaves at dose level of 12 $\mathrm{KGy}$, while it was 81.60 and $81.41 \%$ for 4 and $8 \mathrm{KGy}$ irradiated samples extracts, respectively. No significant difference was found in the scavenging activity of control and radiation-processed samples at 4 and $8 \mathrm{kGy}$. The present findings are in consensus with earlier study conducted by Harrison and Were (2007) they found that, the greatest scavenging ability of almond skin extracts related with the higher total phenolics content of irradiated samples at the higher dose level 12.7 KGy. Also, Khattak et al. (2008) found an enhancement in the free radical-scavenging activity of Nigella sativa seeds extracts with increasing gamma irradiation dose.

Otherwise, data in Table (4) shows the DPPH radical scavenging activities of the methanolic extracts of roots samples as affected by gamma irradiation at different doses. From the results, the extracts of irradiated samples at dose levels of 4,8 and $12 \mathrm{KGy}$ showed a stronger ability to neutralize DPPH radicals than the reference standard (BHT), with followed values 75.60, 74.70 and $67.06 \%$, respectively. The synthetic antioxidant showed the lowest scavenging activity with a value equals to $65.11 \%$. It may be due to the highest content of polyphenolic compounds. Increasing of the antioxidants activity may be caused due to 
fragmentation of hydroxyl group from the sample, hydrogen atoms reacted with free radical, and they convert it into a more stable product (Shah et al., 2015).

Table 4. DPPH radical scavenging activity of the non-irradiated and irradiated chicory leaves and roots powder extracts.

\begin{tabular}{|c|c|c|c|c|c|c|}
\hline \multirow{4}{*}{ Dose (KGy) } & \multicolumn{6}{|c|}{ \% scavenging activity of DPPH } \\
\hline & \multicolumn{3}{|c|}{ Leaves } & \multicolumn{3}{|c|}{ Roots } \\
\hline & \multicolumn{6}{|c|}{ Time (min) } \\
\hline & $\mathbf{0}$ & 30 & 60 & $\mathbf{0}$ & 30 & 60 \\
\hline \multirow{2}{*}{$\mathbf{0}$} & $\mathbf{7 0 . 0 7}^{\mathrm{B}}$ & $80.35^{B}$ & $80.95^{\mathrm{B}}$ & $63.60^{A}$ & $69.27^{\mathrm{B}}$ & $69.73^{B}$ \\
\hline & \pm 0.57 & \pm 0.46 & \pm 0.39 & \pm 1.64 & \pm 0.46 & \pm 1.10 \\
\hline \multirow{2}{*}{4} & $71.96^{\mathrm{AB}}$ & $81.37^{\mathrm{AB}}$ & $\mathbf{8 1 . 6 0}^{\mathrm{B}}$ & $64.01^{\mathrm{A}}$ & $72.25^{\mathrm{A}}$ & $75.60^{A}$ \\
\hline & \pm 1.10 & \pm 0.20 & \pm 0.33 & \pm 0.55 & \pm 0.28 & \pm 0.47 \\
\hline \multirow{2}{*}{8} & $70.27^{\mathrm{B}}$ & $80.72^{\mathrm{AB}}$ & $81.41^{B}$ & $62.92^{\mathrm{A}}$ & $71.69^{A}$ & $74.70^{A}$ \\
\hline & \pm 0.09 & \pm 0.65 & \pm 0.29 & \pm 1.29 & \pm 0.88 & \pm 0.96 \\
\hline \multirow{2}{*}{12} & $72.76^{\mathrm{A}}$ & $81.84^{\mathrm{A}}$ & $82.89^{A}$ & $60.56^{B}$ & $66.29^{C}$ & $67.06^{\mathrm{C}}$ \\
\hline & \pm 0.36 & \pm 0.57 & \pm 0.28 & \pm 0.28 & \pm 0.57 & \pm 1.00 \\
\hline BHT & $29.73^{C}$ & $50.93^{\mathrm{C}}$ & $65.11^{C}$ & $29.73^{C}$ & $\mathbf{5 0 . 9 3}^{\mathrm{D}}$ & $65.11^{C}$ \\
\hline$(200 \mathrm{ppm})$ & \pm 0.20 & \pm 0.06 & \pm 0.42 & \pm 0.20 & \pm 0.06 & \pm 0.42 \\
\hline
\end{tabular}

Values are expressed as mean \pm standard error; means with the same capital letter in the same columns are not significantly different $(p>0.05)$.

BHT: butylated hydroxytoluene

\subsubsection{Ferric reducing antioxidant power (FRAP):}

Data in Table (5) shows the dose-response values for the reducing powers of the various extracts from irradiated chicory leaves and roots samples. It was found that all these extracts exhibited ferric reducing power greatly in dose level dependent manner. The reducing power capacity of all the extracts may provide a significant indication about the potential antioxidant capacity of the plant parts. There was a difference among the different extracts of chicory in reducing power compared to synthetic antioxidants (BHT) as positive control.

Concerning leaves, the ethanolic extract of irradiated leaves sample at dose level of $12 \mathrm{KGy}$ showed the better reducing power than other extracts with value 2.380 (absorbance value) followed by the extracts of 8 and $4 \mathrm{KGy}$ irradiated leaves with values 2.299 and 2.185, respectively. From the results we can notice that there was an increasing of the FRAP in all irradiated leaves samples when compared to non- irradiated sample and an increasing was observed in all extracts with increasing of gamma irradiation dose.

Furthermore, the methanolic extracts of chicory roots showed a promising result in this assay Table (5). An increasing in the ferric reducing power was observed in the extracts of irradiated roots at dose levels of 4 and $8 \mathrm{kGy}$ compared to control sample and $12 \mathrm{kGy}$ dose, and the absorbance value of the extracts exhibited the following order: 4KGy (1.493) > 8KGy $(1.437)>12 \mathrm{KGy}(1.283)>$ control (1.202). From these results, overall, the extract of irradiated roots at dose level of $4 \mathrm{KGy}$ has the highest value and exhibited a potent reducing power when compared to the other extracts and synthetic antioxidants (BHT).

The results indicated that there was a correlation between the ferric reducing antioxidant power and phenolic contents of the extracts. This emphasizes the importance of phenolic contents in reducing power observed in this study, and this may be due to their potent electron donating abilities (Llorach et al., 2004 and Bilto et al., 2012).

Table 5. Ferric reducing antioxidant power (O.D) of non-irradiated and irradiated chicory leaves and roots powder extracts:

\begin{tabular}{ccc}
\hline $\begin{array}{c}\text { Dose } \\
(\text { KGy })\end{array}$ & Leaves & Roots \\
\hline 0 & 1.992 & 1.202 \\
\hline 4 & 2.185 & 1.493 \\
\hline 8 & 2.299 & 1.437 \\
\hline 12 & 2.380 & 1.283 \\
\hline BHT $(200 \mathrm{ppm})$ & 1.019 & 1.019 \\
\hline
\end{tabular}

\subsection{Antimicrobial activity of chicory leaves and roots extracts:}

As shown in Table (6) all of the extracts exhibited considerable antibacterial activity against all tested microorganisms with slightly differences between plant part, strains variety and gamma irradiation dose. 
Data indicated that there were observable significant differences between extracts of the control and irradiated chicory leaves at dose level of $12 \mathrm{KGy}$ regarding growth inhibition of $B$. cereus, $S$. aureus, $K$. pneumonia and P.aeruginosa. The inhibition zones of the previous tested bacteria reached its maximal values $35,39,31$ and $35 \mathrm{~mm}$, respectively at dose level of $12 \mathrm{kGy}$. Meanwhile, the highest inhibition of E.coli was $27 \mathrm{~mm}$ and achieved by the extract of $8 \mathrm{KGy}$ irradiated leaves. Also, nonsignificant changes in inhibition zone were observed in the $4 \mathrm{kGy}$ irradiated leaves when compared to that of the $8 \mathrm{KGy}$ irradiated leaves for $B$. cereus, $K$. pneumonia and $P$. aeruginosa.

On the other hand, in the case of roots, the methanolic extract of irradiated roots at dose level of 4KGy showed the highest antibacterial potency against $B$. cereus, $S$. aureus, $K$. pneumonia and
P.aeruginosa with inhibition zones 28, 27, 26 and $29 \mathrm{~mm}$, respectively compared to control sample and other doses. However, the extract from the nonirradiated roots performed significantly higher than the irradiated roots extracts in the inhibition of the growth of E.coli, the inhibition zones were 31, 22, 17 and $17 \mathrm{~mm}$ for $0,4,8$ and $12 \mathrm{KGy}$ irradiated roots, respectively. From the statistical analysis, there were nonsignificant differences between 4 and $8 \mathrm{KGy}$ for the inhibition of B. cereus, S. aureus, K. pneumonia and $P$. aeruginosa.

Khattak (2012) and Pereira et al. (2017) declared that, nonsignificant differences were noted in the antibacterial activity of the irradiated Fagonia arabica and lemon verbena extracts as influenced by gamma irradiation treatment up to dose level of 10 kGy.

Table 6. Antimicrobial activity of non-irradiated and gamma irradiated chicory leaves and roots powder extracts.

\begin{tabular}{|c|c|c|c|c|c|c|c|c|}
\hline \multirow{3}{*}{ 氞 } & \multirow{3}{*}{ 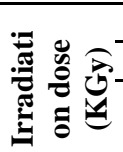 } & \multicolumn{7}{|c|}{ Inhibition zone (mm) } \\
\hline & & & & & sted organis & & & \\
\hline & & $\begin{array}{c}\text { B. } \\
\text { Cereus }\end{array}$ & $\begin{array}{c}\text { S. } \\
\text { Aureus }\end{array}$ & $\begin{array}{c}E . \\
\text { coli }\end{array}$ & $\begin{array}{c}P . \\
\text { aeruginosa }\end{array}$ & $\begin{array}{c}\text { K. } \\
\text { pneumonia }\end{array}$ & $\begin{array}{c}A . \\
\text { niger }\end{array}$ & $\begin{array}{c}P . \\
\text { expansum }\end{array}$ \\
\hline \multirow{4}{*}{ 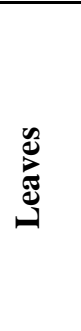 } & $\mathbf{0}$ & $\begin{array}{c}\mathbf{2 8}^{\mathrm{C}} \\
\pm 1.00\end{array}$ & $\begin{array}{c}\mathbf{3 3}^{\mathbf{B}} \\
\pm 0.57\end{array}$ & $\begin{array}{c}\mathbf{2 6}^{\mathbf{A}} \\
\pm 0.99\end{array}$ & $\begin{array}{c}\mathbf{2 7} \mathbf{C} \\
\pm 1.15\end{array}$ & $\begin{array}{c}\mathbf{2 3}^{\mathbf{B}} \\
\pm 0.69\end{array}$ & - & - \\
\hline & 4 & $\begin{array}{c}\mathbf{3 1} \text { B } \\
\pm 0.57\end{array}$ & $\begin{array}{c}\mathbf{3 5}^{\mathbf{A}} \\
\pm 1.20\end{array}$ & $\begin{array}{c}\mathbf{2 1}^{\mathbf{B}} \\
\pm 1.15\end{array}$ & $\begin{array}{l}\mathbf{3 3}^{\mathbf{A B}} \\
\pm 0.57\end{array}$ & $\begin{array}{c}\text { 30 }^{\mathrm{A}} \\
\pm 0.63\end{array}$ & - & - \\
\hline & 8 & $\begin{array}{c}\mathbf{3 2}^{\mathbf{B}} \\
\pm 0.72\end{array}$ & $\begin{array}{c}\mathbf{2 7} \text { B } \\
\pm 0.57\end{array}$ & $\begin{array}{c}\mathbf{2 7}^{\mathbf{A}} \\
\pm 1.00\end{array}$ & $\begin{array}{c}\mathbf{3 1}^{\mathbf{B}} \\
\pm 0.99\end{array}$ & $\begin{array}{c}\mathbf{3 1} \mathbf{A}^{\mathbf{A}} \\
\pm 1.00\end{array}$ & - & - \\
\hline & 12 & $\begin{array}{c}\mathbf{3 5}^{\mathbf{A}} \\
\pm 1.12 \\
\end{array}$ & $\begin{array}{r}\mathbf{3 9}^{\mathrm{A}} \\
\pm 1.52 \\
\end{array}$ & $\begin{array}{c}\mathbf{2 0}^{\mathbf{B}} \\
\pm 0.88 \\
\end{array}$ & $\begin{array}{c}3^{\mathbf{A}} \\
\pm 0.57 \\
\end{array}$ & $\begin{array}{c}\mathbf{3 1}^{\mathbf{A}} \\
\pm 0.57 \\
\end{array}$ & - & - \\
\hline \multirow{4}{*}{$\frac{\mathscr{0}}{\mathscr{0}}$} & $\mathbf{0}$ & $\begin{array}{c}\mathbf{2 1}^{\mathbf{B}} \\
\pm 1.00\end{array}$ & $\begin{array}{c}\mathbf{2 3}^{\mathbf{B C}} \\
\pm 0.57\end{array}$ & $\begin{array}{c}\mathbf{3 1} \mathbf{A}^{\mathbf{A}} \\
\pm 1.15\end{array}$ & $\begin{array}{c}\mathbf{2 5}^{\text {B }} \\
\pm 1.00\end{array}$ & $\begin{array}{c}\mathbf{2 5}^{\mathrm{A}} \\
\pm 1.52\end{array}$ & - & - \\
\hline & 4 & $\begin{array}{c}\mathbf{2 8}^{\mathbf{A}} \\
\pm 0.57\end{array}$ & $\begin{array}{c}\mathbf{2 7}^{\mathbf{A}} \\
\pm 1.00\end{array}$ & $\begin{array}{c}\mathbf{2 2}^{\mathbf{B}} \\
\pm 1.52\end{array}$ & $\begin{array}{c}\mathbf{2 9} \\
\pm 0.57\end{array}$ & $\begin{array}{r}\mathbf{2 6}^{\mathbf{A}} \\
\pm 1.0\end{array}$ & - & - \\
\hline & 8 & $\begin{array}{c}\mathbf{2 7}^{\mathbf{A}} \\
\pm 0.99\end{array}$ & $\begin{array}{l}\mathbf{2 5} \mathbf{A B} \\
\pm 0.57\end{array}$ & $\begin{array}{c}17^{\mathrm{C}} \\
\pm 0.57\end{array}$ & $\begin{array}{l}\mathbf{2 7} \mathbf{A B} \\
\pm 0.57\end{array}$ & $\begin{array}{c}\mathbf{2 5}^{\mathbf{A}} \\
\pm 0.57\end{array}$ & - & - \\
\hline & 12 & $\begin{array}{c}\mathbf{1 5}^{\mathrm{C}} \\
\pm 0.57\end{array}$ & $\begin{array}{c}\mathbf{2 0}^{\mathrm{C}} \\
\pm 1.527\end{array}$ & $\begin{array}{c}\mathbf{1 7}^{\mathrm{C}} \\
\pm 1.00\end{array}$ & $\begin{array}{l}\mathbf{2 8} \mathbf{A} \\
\pm .00\end{array}$ & $\begin{array}{c}\mathbf{2 4}^{\mathbf{A}} \\
\pm 1.52\end{array}$ & - & - \\
\hline
\end{tabular}

- : no inhibition zone

Values are expressed as mean \pm standard error; means with the same capital letter in the same columns are not significantly different $(p>0.05)$.

Finally, the obtained results showed that, all of the extracts from non-irradiated and irradiated leaves and roots had no antifungal activity against $A$. niger and $P$. expansum. This is an agreement with (Liu et al., 2013) they found that, the fungi Penicillium $s p$. and Aspergillus $s p$. were the most resistant to all the chicory root extracts and no inhibition activity was found.

Also, Khattak and Simpson (2010) reported that, the antifungal activities of Glycyrrhiza glabra extract against A. flavus, A. niger, Candida albicans, Epidermophyton floccosum and Trichoderma viride were not affected by gamma irradiation up to $25 \mathrm{kGy}$ doses.
The obtained data showed that, all tested parts of chicory contain considerable amounts of phytochemicals and are good source of antioxidants. Thus, chicory would play an important role in antioxidant defense system against endogenous free radicals because of their good antibacterial and antioxidant composition. Also these results are good basis for utilization of this plant for further pharmaceutical and food industries. Irradiation treatment was found to be superior for improving the phytochemical, antioxidant and antimicrobial activities and the most indicated doses to maintain phytochemicals content, and to increase antioxidant activity as well as antimicrobial were 4 and $12 \mathrm{KGy}$ for roots and leaves, respectively.

\section{References}

\section{Conclusions}


Alothman, M.; Bhat, R. and Karim, A. A. (2009). Effects of radiation processing on phytochemicals and antioxidants in plant produce. Trends in Food Sci. and Tech., 20(2):201- 212.

A.O.A.C (2012). Official Methods of Analysis Association of Official Analytical Chemists International, $19^{\text {th }}$ Ed., Maryland, USA.

Arabshahi-Delouee, S. and Urooj, A. (2007). Antioxidant properties of various solvent extracts of mulberry (Morus indica L.) leaves. Food Chemistry, 102 (4):1233-1240.

Baydar, N.; Özkan, G. and Sagdiç, O. (2004). Total phenolic contents and antimicrobial activities of grape (Vitis vinifera L.) extracts. Food Control, 15: 335-339.

Behgar, M.; Ghasemi, S.; Naserian, A.; Borzoie, A. and Fatollahi, H. (2011). Gamma radiation effects on phenolics, antioxidants activity and in vitro digestion of pistachio (Pistachia vera) hull. Radiation Physics and Chemistry, 80: 963-967.

Ben Salem, I.; Fekih, S.; Sghaier, H.; Bousselmi, M.; Saidi, M.; Landoulsi, A. and Fattouch, S. (2013). Effect of ionising radiation on polyphenolic content and antioxidant potential of parathion-treated sage (Salvia officinalis) leaves. Food Chemistry, 141:1398-1405.

Bilto, Y.Y.; Suboh, S.; Aburjai, T. and Abdalla, S. (2012). Structure-activity relationships regarding the antioxidant effects of the flavonoids on human erythrocytes. Nat. Sci., 9: 740-747.

Brand-Williams, W.; Cuvelier, M.E. and Berset, C. (1995). Use of a free radical method to evaluate antioxidant activity. Lebensm. Wiss. Technol., 28: 25-30.

Breitfellner, R.; Solar, S. and Sontag, G. (2002). Effect of gamma irradiation on phenolic acids in strawberries. Journal of Food Science, 67: 517521.

Carazzone, C.; Mascherpa, D.; Gazzani, G. and Papetti, A. (2013). Identification of phenolic constituents in red chicory salads (Cichorium intybus) by high performance liquid chromatography with diode array detection and electrospray ionisation tandem mass spectrometry. Food Chemistry, 138: 1062-1071.

Clifford, M. N. (2000). Chlorogenic acids and other cinnamates nature, occurrence, dietary burden, absorption and metabolism. J. Sci. Food Agric., 80: 1033-1043.

Darfour, B.; Agbenyegah, S.; Ofosu, D.O.; Okyere, A.A. and Asare, I.K. (2014). Gamma irradiation of Tetrapleura tetraptera fruit as a post-harvest technique and its subsequent effect on some phytochemicals, free scavenging activity and physicochemical properties. Radiation Physics and Chemistry, http://dx.doi.org/10.1016/j.radphyschem.2014.05. 003

Denev, P.; Petkova, N.; Ivanov, I.; Sirakov, B.; Vrancheva, R. and Pavlov, A. (2014).
Determination of biologically active substances in taproot of common chicory (Cichorium intybus L.). Scientific Bulletin Series F. Biotechnologies, XVIII: 124- 128 .

Eslami, H. (2015). Investigation the effects of used solvent components proportions for extraction the antimicrobial compounds of Cichorium intybus L. on their antibacterial and antifungal activities. Int. J. Biosci., 6(7):73-81.

Faiku, F.; Hazirim, A.; Mehmeti, I.; Bajrami, D. and Haziri, I. (2016). Evaluation of antibacterial activity of different solvent extracts of Cichorium intybus (L.) growing wild in east part of Kosovo. J. Anim. Plant Sci., 26(5):1486-1491.

Goupy, P.; Hugues, M.; Boivin, P. and Amoit, M.J. (1999). Antioxidant composition and activity of barley (Hordeum vulgare) and malt extracts and of isolated phenolic compounds. J. Sci. Food Agric., 79:1625-1634.

Harrison, K. and Were, L.M. (2007). Effect of gamma irradiation on total phenolic content yield and antioxidant capacity of almond skin extracts. Food Chemistry, 102:932-937.

Javed, M.S.; Khan, M.I.; Randhawa, M.A.; Sajid, M.W.; Khan, A.A. and Nasir, M.A. (2011). Garlic (Allium Sativum L.) as an antimicrobial and antioxidant agents in beef sausages. Pak. J. Food Sci., 21(1-4): 22-32.

Judzentiene, A. and Udiene, J.B. (2008). "Volatile constituents from aerial parts and roots of Cichorium intybus L. (chicory) grown in Lithuania". Chemija, 19: 25-28.

Kaur, H.P.; Singh, I. and Singh, N. (2016). Phytochemical, antioxidant and antibacterial potential of extracts of Cichorium intybus (chicory). EJPMR., 3(12): 320-326.

Khan, A.S.; Hassan, M. and Ali, S. (2014). Secondary metabolite studies of some selected plants of district Gilgit, Gilgit-Baltistan. International Journal of Pharmacognosy and Phytochemical Research, 6(3): 467-471.

Khattak, K.F. (2012). Evaluation of microbial loads, physical characteristics, chemical constituents and biological properties of radiation processed Fagonia arabica. Radiation Physics and Chemistry, 81: 679-685.

Khattak, K. F. (2013). Proximate composition, phytochemical profile and free radical scavenging activity of radiation processed Emblica offcinalis. International Food Research Journal, 20(3): 11251131.

Khattak, K.F. and Simpson, T.J. (2010). Effect of gamma irradiation on the antimicrobial and free radical scavenging activities of Glycyrrhiza glabra root. Radiation Physics and Chemistry, 79: 507512.

Khattak, K.F.; Simpson, T.J. and Ihasnullah, A. (2008). Effect of gamma irradiation on the extraction yield, total phenolic content and free- 
radical scavenging activity of Nigella sativa seed. Food Chemistry, 110, 967-972.

Liu, H.; Wang, Q.; Liu, Y.; Chen, G. and Cui, J. (2013). Antimicrobial and antioxidant activities of Cichorium Intybus root extract using orthogonal matrix design. Journal of Food Science, 78(2):253268.

Llorach, R.; Tomaäs-barberaän, F.A. and Ferreres, F. (2004). Lettuce and chicory byproducts as a source of antioxidant phenolic extracts. J. Agric. Food Chem., 52: 5109-5116.

Massoud, M.I.; Amin, W.A. and Elgindy, A.A. (2009). Chemical and Technological Studies on Chicory (Cichorium Intybus L) and Its Applications in Some Functional Food. J. Adv. Agric. Res., 14(3): 735-756.

Monti, A.; Amaducci, M.T.; Pritoni, G. and Venturi, G. (2005). Growth, fructan yield, and quality of chicory (Cichorium intybus L.) as related to photosynthetic capacity, harvest time, and water regime. Journal of Experimental Botany, 56:1389-1395.

Moosavi, K.S.; Hosseini, S.; Dehghan, G. and Jahanban-esfahlan, A. (2014). The effect of gamma irradiation on phytochemical content and antioxidant activity of stored and nonestored Almond (Amygdalus communis L.) Hull. Pharm Sci., 20(3):102-106.

Mulabagal, V.; Wang, H.B.; Ngouajio, M. and Nair, M.G. (2009). Characterization and quantification of health beneficial anthocyanins in leaf chicory (Cichorium intybus) varieties. Eur. Food Res. Technol., 230(1):47-53.

Ordon, J.D.; Gomez, M.A. and Vattuone, M.I. (2006). Antioxidant activities of Sechium edule (Jacq.) Swartz extracts. Food Chemistry, 97:452-458.

Oyaizu, M. (1986). Studies on products of browning reactions: antioxidative activities of browning reaction prepared from glucosamine. Jpn. J. Nutr., 44: 307-315.

Papetti, A.; Maietta, M.; Corana, F.; Marrubini, G. and Gazzani, G. (2017). Polyphenolic profile of green/red spotted Italian Cichorium intybus salads by RP-HPLC-PDA-ESI MS ${ }^{n}$. Journal of Food Composition and Analysis, http://dx.doi.org/10.1016/j.jfca.2017.08.010

Pereira, E.; Pimenta, A.I.; Calhelha, R.C.; Antonio, A.L.; Barros, L.; Santos-Buelga, C.;
Verde, S.C. and Ferreira, I.C.F.R. (2017). Infusions of gamma irradiated Aloysia citrodora L. and Mentha $x$ piperita L.: Effects on phenolic composition, cytotoxicity, antibacterial and virucidal activities. Industrial Crops and Products, 97: 582-590.

Saggu, S.; Sakeran, M.I.; Zidan, N.; Tousson, E.; Mohan, A. and Rehman, H. (2014). Ameliorating effect of chicory (Cichorium intybus L.) fruit extract against 4-tert-octylphenol induced liver injury and oxidative stress in male rats. Food and Chemical Toxicology, 72: 138-146

Sahan, Y.; Gurbuz, O.; Guldas, M.; Degirmencioglu, N. and Begenirbas, A. (2017). Phenolics, antioxidant capacity and bioaccessibility of chicory varieties (Cichorium spp.) grown in Turkey. Food Chemistry, 217: 483489.

Sarvankumar, G.; Riyazullah, M.S.; Rajesh, B. and Santhosh (2011). Pharmacognostical profiles on Cichorium intybus Linn. leaves. International Research Journal of Pharmacy, 2(11): 85-87.

Shah, A.; Masoodi, F.A.; Gani, A. and Ashwar, B.A. (2015). Effect of $\gamma$-irradiation on antioxidant and antiproliferative properties of oat $\beta$-glucan. Radiat Phys Chem., 117:120-7.

Shaikh, T.; Rub, R.A. and Sasikumar, S. (2012). Antimicrobial screening of Cichorium intybus seed extracts. Arabian Journal of Chemistry, http://dx.doi.org/10.1016/j.arabjc.2012.04.012.

Shin, S. and Lim, S. (2004). Antifungal effects of herbal essential oils alone and in combination with ketoconazole against Trichophyton spp. J. of App. Microbiol., 97:1289- 1296.

Shui, G.H. and Leong, L.P. (2004). Analysis of polyphenolic antioxidants in star fruit using liquid chromatography and mass spectrometry. J. Chromatogr. A., 1022: 67-75.

Sudhanshu; Rao, N.; Mittal, S. and Menghani, E. (2012). In vitro antioxidant activity and phytochemical screening of the methanolic extract of Cichorium intybus. International Journal of Chemical and Pharmaceutical Sciences, 3 (2):1316.

Yalcin, H.; Ozturk, I.; Tulukcu, E. and Sagdic, O. (2011). Effect of gamma-irradiation on bioactivity, fatty acid compositions and volatile compounds of Clary sage seed (Salvia sclarea L.). Journal of Food Sciences, 76(7):1056-1061. 


\section{النشاط المضاد للأكسدة والميكرويات لأورلق وجذور الهندباء المعاملة بأشعة جاما}

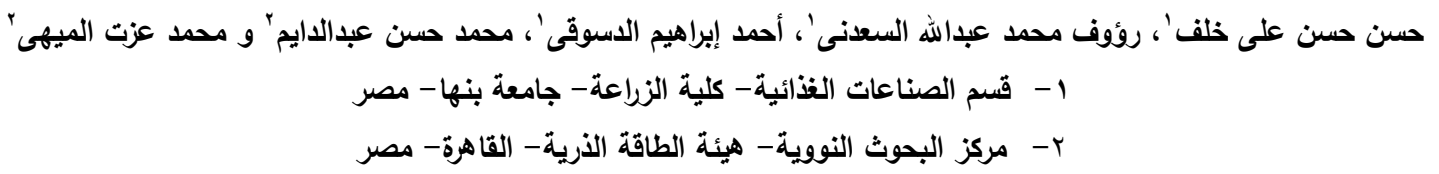

تهدف هذه الدراسة الى تقييم النشاط المضاد للأكسدة والميكروبات لكل من المستخلص الإيثانولى والميثانولى (.0\%) لأوراق وجذور نبات

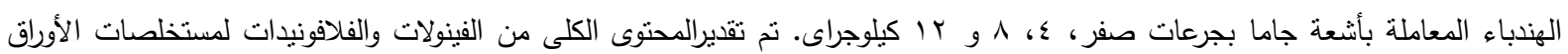
والجذور وكذلك النشاط المضاد للأكسدة بإستخدام طريقتى DPPH و DRAP، والتعرف على المركبات الفينولية بإستخدام HPLC. (B. cereus, S. aureus, E. coli, P. aeruginosa, K. pneumonia, A. niger and P. expansum) النشاط المضاد للميكروبات بطريقة Agar well diffusion. وقد أظهرت النتائج أن المستخلص الإيثانولى للأوراق يحتوى على نسبة أعلى من الفينولات والفلافونيدات وفاعلية

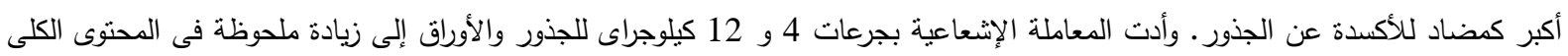
للفينولات والفلافونيدات والنشاط المضاد للأكسدة. بالإضافة إلى ذلك، نم التعرف على ثنلاثة وعشرون مركب فينولى فى مستخلصات الإتهات الجذور والأوراق

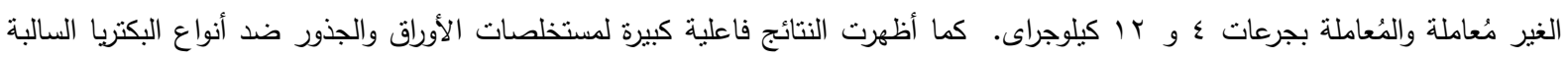

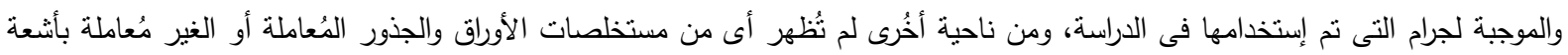

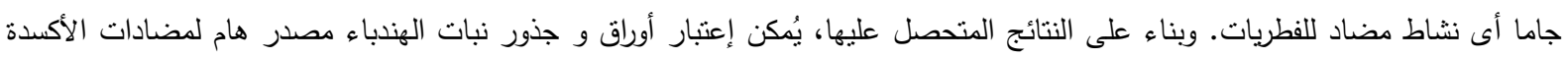
الطبيعية ومضاد لنمو والبكتريا ويمكن استخدامه فى مجال الصناعات الغذائية لإنتاج غذاء أمن صحياً كما يمكن إستخدامها في مجاء مجال الصناء الصناعات 